\title{
The Creative Launcher
}

\author{
(2455-6580) \\ An International, Open Access, Peer-Reviewed \& Refereed Journal in English \\ https://www.thecreativelauncher.com \\ Vol. 6 \& Issue 3, (August-2021) - pp-123-129
}

DOI: 10.53032/TCL.2021.6.3.24

\section{Epic Woman Stepping into Reality: Depiction of Draupadi with a Feminist Lens with Reference to Three Indian Novels}

\author{
Prof. Prajakta S. Raut \\ Head, Department of English, \\ Abhinav Degree College, \\ Goddeo, Bhayander (E) \\ Email id-prajaktaraut78@gmail.com
}

ORCID id- 0000-0002-7396-8333 One is not born but rather becomes a woman. It is the civilization as a whole that
produces this creature which is described as feminine.

-Simone de Beauvoir, The Second Sex (1949)

\begin{abstract}
Lower status of women is a stain on any society. The problem is becoming glaring in India in the wake of atrocities caused against women 'from womb to tomb'. Even in this twenty first century, the impact of manuvadi ideology is getting evidently felt. 'A thinking woman spoils everything' is still the mindset. Maladies like honour killing, bride burning are still gloating over the security of women in the wake of the internalized mindset of patriarchal dictum, viz. 'A woman does not deserve any freedom' (Na stri swatantryam arhati). Since time immemorial, she was always taken for granted though she had never remained silent. The depiction of Draupadi in various writings underscores woman's protest against male dichotomy and her refusal to live by disabling definitions that mark women as inferior.
\end{abstract}

Keywords- Atrocities, Protest, Maladies, Menace, Freedom, Subjugation

\section{Introduction}

When one comes across any piece of literature, be it Indian, African, British, American, ancient or modern, Oriental or Occidental, what captivates readers' attention is her perennial exploitation or subsumption under men and her overt or covert protest against it. "But why should there be any confrontation? Since the story of human race begins with the female. It is she who carried the original human chromosome as she does to this day. Yet, for generations, the historians have always regarded 'man' as the star whereas in reality, the woman was quietly getting on with the task of securing a future for humanity: for it was her labours, her Skills, her biology that held the key to the destiny of her race." (Tapaswi: 36). But the paradox was that she got termed to be "incidental, the inessential as opposed to the essential and he...the subject, the absolute. She...the other," ${ }^{2}$ despite her justification as the very backbone for maintenance of life.

The further height was that this derogatory viewpoint regarding woman as passive, acquiescent, timid, emotional and conventional got reflected even in the literature of the time as the

CPerception Publishing House, 2021. This Open Access article is published under a Creative Commons Attribution NonCommercial 4.0 International License https://creativecommons.org/licenses/by-nc/4.0/, which permits non-commercial re-use, distribution, and reproduction in any medium, provided the original work is properly cited. For citation use the DOI. For commercial re-use, please contact editor on:- thecreativelauncher@gmail.com 
relationship between literature and society is axiomatic. In the context of India, it became more evident with the presentation of female characters viz. Shakuntala, Malavika, Vasavdatta, Kadambari, Malati by writers like Kalidasa (Abhidnyashakuntalam and Malacikagnimitram), Bhasa (Swapnavasavdatta), Banabhatta (Kadambari) or Bhavbhuti (Malatimadhava), which foreshadowed rather glaring facts of patriarchy "by leaving the women reader an alien outsider or solicit(ing) her to identify against her by taking up the position of the Male subject and so assuring Male values and ways of perceiving." 3 (Abrahams: 235). What was more ambivalent was on the one hand, a woman was honoured as Goddess or a queen, so quite complementary to masculine interests; to protect her dignity, wars were fought in Ramayana and Mahabharata; on the other hand, she had been deprived of everything. Men enjoyed all possible freedom and their misbehavior was not only paradosed but many a time was respected under the pretext of purushartha as was the case with the tragic plight met by Amba in 'Mahabharata'. But next to Amba, it is only Draupadi, the wife of five Pandavas, who appears to be most poignant and so grabs critics' attention. The 'emerged' daughter of king Drupada of Panchal, the common wife of five Pandavas, the lady with flawless, unsurpassed beauties, one of the Panch-kanyas (The five Virgins) of the ancient Hindu epic has been an enigmatic woman of substance for many; so occupies pivotal place in literary creation. The current research paper is confined to Yuganta: The End of an Epoch (1967) by Iravati Karve, Yadnyaseni (1987) by Pratibha Rai, Mrutunjaya (The Death Conqueror 1995) by Shivaji Sawant and The Palace of Illusions (2008) by Chitra Banerjee Divakaruni, hinging largely round her unusual marital relationship through polyandry, "(that) was not regarded without censure by the society spoken of in the epic...although polygamy was common among men of higher social ranks," ${ }^{4}$ and her protest against the existing dichotomy at the play of dice, which makes her quite deviant and ahead of time.

\section{Problem Statement:}

Draupadi is a Proto- feminist figure in Hindu mythology, being downright, who interrogated the Patriarchal ideology throughout life in her outright call for femocracy.

\section{Objectives of the Study:}

1) To enlighten the gender specific awareness that to be born a woman does not mean to be born into servitude

2) To make the audience irrespective of the gender aware of the fact that a woman is not to be taken for granted or subsumed under masculine desires.

\section{Benefits of the Study:}

This research is expected to give following Benefits:

\section{1) Theoretical Benefit:}

To awaken the consciousness of recipients regarding the fact that both man and woman are complementary to each other, being wheels of the same chariot.

\section{2) Practical Benefit:}

To bring out societal changes in Day to Day life that a woman is not 'a Barbie doll' to be bought or sold and her sacrifice in domestic affairs is to be acknowledged.

\section{Research Method:}

1) Type of the Research:

In this research, the writer resorts to Descriptive- Qualitative Method.

2) Type of Data Required for the Study:

a. Primary Data: The Primary data sources of the study are the novels Yuganta: The End of an Epoch (1967) by Iravati Karve, Yadnyaseni (1987) by Pratibha Ray, Mrutunjaya (1995) by Shivaji Sawant and The Palace of Illusions (2008) by Chitra Banerjee Divakaruni. 
b. Secondary Data: The secondary sources of data comprise background information in the form of socio- economic milieu of time, interviews of the writers published and telecasted, book reviews, etc.

\section{Techniques of Data Collection:}

In this case, the writer uses two techniques of collecting data:

a) Observation: This step is used to make our research more penetrative, by reaching the depth of the matter which involves actual reading of the novels.

b) Library Research: This involves reading background information, reviews by experts apart from the epic stories of Mahabharata in translations.

\section{Technique of Data Analysis:}

Our research paper is Descriptive and Qualitative and so the character of Draupadi is appraised from feminist perspectives who was not 'acquiescence to subjugation 'but a rebel.

\section{Literature Review:}

Draupadi's acceptance of polyandry "being the Deva's tradition was quite counter to the spirit of the age since according to the ethical code of those days, "A lady who had sexual contact with four is called 'Swairini' (who does not follow any ethical or moral code) and the one who has it with five is a prostitute." 5

Now the question is whether her acceptance was through all her heart or imposed on her. Mahabharata says that her acceptance of polyandry was the consequent result of her past birth action. In the former birth, she was born as Nalayani (daughter of Nala and Damayanti). She had in that lifetime prayed to Shiva to grant her a husband with fourteen desires qualities. She was resolute in her wish. Then Lord Shiva granted her wish saying that she would get the same in her next birth with five husbands. She was shocked and asked Lord Shiva if it was a boon or curse. Shiva replied saying that she would regain her virginity each and every morning she takes bath and till the end of her life she would live with virginity. He further placated her that the boon would apply to her next life when she would be born into a culture more accepting of polyandry; the mightiness of fate just works in the direction of fulfilling the prophecy as was ordained, i.e. she gets married to brothers, each of them represents a given quality. The Just Yudhishthira for his wisdom of Dharma, the powerful Bhima for his strength that exceeded that of a thousand elephants combined, the valiant Arjuna for his courage and knowledge of the battlefield, the exceedingly handsome Nakula and Sahadeva for their love. The five Pandavas were said to have the fourteen qualities desired by Draupadi in her previous birth.

Thus, the pattern to have remained incomplete in the former birth gets fructified in the second birth, thwarting all endeavors to get united with Karna for whom she had felt irresistible fascination from the very beginning. In The Palace of Illusions (2008), it has been said that before her Swayamvara, she was shown the portraits of the prospective suitors. While seeing the portraits of Kaurava princes, Duryodhana and Dusasana, she notices Karna also painted in the portraits. She was immediately gravitated towards him, especially some ancient, enigmatic ache and feels to zero him down, at the cost of the portrait of Arjuna. But since the situation didn't have it and Krishna intervenes, stops the growth of tender feelings. He even reproaches the artist for showing the picture of Karna to Draupadi, as Karna does not belong to eminent section of society, was not a Pprince. He even belittles him by saying that his kingdom is a gift and Karna is just a son of a chariot driver. So recollecting Sorceress's words that "love comes like lightening and disappears the same way. If you are lucky, it strikes you right. If not, you will spend your life yearning for a man you can't have." (Divakaruni, p-63), one finds Draupadi to be burning in the agony of not having the man for whom 


\section{The Creative Launcher | Vol. 6 \& Issue 3 (August, 2021)|126}

she had developed the tender feelings of desire and bearing the punishment of satisfying five to serve the political purpose.

Even in the 'Swayamvara' it was Drishtdhyuma who first raised objection to Karna as being a son of the charioteer, competing for Draupadi's hand. Since true love is beyond all the barriers of caste, culture and creed, Ethnocentrism did not block her fascination for this simple and masculine personality, "I longed to look into Karna's face to see if those eyes were indeed as sad as the artist had portrayed, but even I know how improper that would be. I focused on his hands, the wrists, disdainfully bare of ornaments, the powerful battered knuckles" (Divakaruni P-93).

However, the mightiness of fate conspires against her desires by nipping in the bud the tender feelings for Karna. Eminence bias remarks by Dushtyadhyuma insult Karna stirring a dual. Being a 'well-behaved', 'cultured' princess, she had to stand in support of her brother saying na ham varyami sutam (I won't wed a charioteer), even when in heart of heart, the wounded face of Karna was pricking her:

In the face of that question (since he did not belong to eminent Section), Karna was silenced.

Defeated, head bent in shame, he left the marriage hall. But, he never forgot the humiliation of that moment in full sight of all the kings of Bharat. And when the time came for him to repay the naughty princess of Panchal, he did so a hundred fold. (Divakaruni,P-95)

Later, Arjuna, disguised as a Brahmin wins the contest. Since Brahmins were considered to be of noble section as Brahmam Janati iti, Draupadi had to garland him and follow him, barefoot on cracked, burning path. She falls, her knees and palms get cuts. Being a dutiful husband, Arjuna nurses her. So forcing karna out of her mind, she prepares herself to accept Arjuna as her husband. She even repeats different virtues of Arjuna like being courteous, handsome and begins to believe that he would be a suitable husband for her. She tries to convince herself that she would no longer waste time on regret, that she would turn her face to future. She would satisfy herself with duty and if she was lucky, love would come. (Divakaruni, $\mathrm{p}-97$ )

But, fortune plays its mischief once again. Like stars' tennis balls, struck and handed which way please them, it breaks her heart for its sport. Through the medium of Bhima, the malefic impact of stars, has its sway. As they reach the hamlet where Pandavas were hiding, Bheema decides to play a prank by telling their mother that they have brought alms and Kunti unknowingly tells them to share whatever they had got among themselves. Yudhishthira makes Kunti aware of the blunder she had committed. Still, she refuses to change her words:

By doing so, she (wanted to achieve) their integrity in a subtle way. She just curbed their efforts to disintegrate them from each other before they originated in the mind of Duryodhana." 6 (Bhagavat, 62-3)

And partly, her suffering from a sort of inferiority complex if one looks at it from an ethical angle since "she had conceived through Niyoga, which was considered as illegitimate at that time. (So) she must have consciously felt the need for another instance of the same kind." (Manimalini, 32) and compels Draupadi "to accept five husbands for the betterment of the society and the upliftment of Dharma...You must consider yourself lucky for this... Many people would not get an opportunity to achieve such martyrdom." (Rai, 46)

It was literally a jolt for Draupadi. What she had anticipated and what destiny was unveiling before her were poles apart. She was too annoyed and disillusioned by the insistence on Kunti's part:

In my heart of heart strongly opposed the proposal. Could I not have an opinion of my own? What does the Swayamvara mean? What act of bravery have these brothers- other than Arjunaperformed to claim me? (Rai: 21) 
She expects Arjuna to stand up for her and say that she is committed only to him. But, too cultured, a 'virtuous, well-groomed' Prince holds firm, loyal to his family. Even her father and brother discuss about her feasibility of marrying five Pandavas with sole intention of minding family honour and tradition.

Vyasa was consulted to get over the problem. But he merely magnifies her dejection by saying that she should marry them; to soothe her anxiety, he further adds fuel that she would become a virgin after each year, when she is the next brother's wife, leaving her just wondering if the arrangements were all for the benefit of the men and not her, i.e. she would have preferred the gift of having no memory rather than of virginity. Nobody gives any heed to her wish and so one finds her to be too furious at man's world where women's wishes are not considered and compelled to live by disabling definitions that mark them as inferior. So are subsumed under them and always taken for granted.

Thus, the supremely mightier, horrendous force accomplishes the design which was woven through the incidents of her former birth in an unfathomable manner, which was beyond everybody's comprehension as the present life is nothing but a fragment in the pattern of continuity of existence. As it was pre-written and ordained, nobody could rewrite it further including Krishna, incarnation of Lord Vishnu, the God of Sustenance in the pattern of Trinity.

As regards to the matter of her protest against male authority during the time of the game of dice, it has to be deplorably stated that Draupadi is a long suffering victim not only of male bias but also internalised psyche developed by women in the wake of andro-centric ideology, compelling women to twist from the point of view of men. Jyoti Tiwari denounces her of being "the first feminist who gave idea how to use and enjoy everything and then blame it all on men." ${ }^{77}$ For her, the so- called rape drama or for that matter, the disrobing instance in her life was the result of the deed which she had committed deliberately to insult Duryodhana. In accordance with the saying ill-deeds stick to us and good deeds come back to us, Draupadi's ill-karma reverted on her. As 'Mahabharata 'says, Pandavas invited Duryodhana to their palace of illusion constructed by the demon Maya. As ill-luck would have it, Duryodhana stepped on floor which was actually a pool and was actually drenched in water. On this, Draupadi insulted not only him but his father also saying, "Son of a blind would be blind himself":

Any man to whom a person abuses with the name of father will feel humiliated. (So) Duryodhana decided to teach her a lesson. The war of Mahabharata... started from this very statement of Draupadi. ${ }^{8}$ (Tiwari: Ibid)

So, nobody is to be held responsible for his or her own ill-fate. Because everybody gets what he or she deserves by karma:

(But) like any other feminist, (Draupadi) never took responsibility of her actions; only blamed others.(Being) smart, she knew how to use rape drama in her favor and she got sympathies not only in that age but, today also after thousands of years. (Tiwari: Ibid)

Unable to obliviate the humiliation, Duryodhana, together with his brothers, his friend Karna and maternal uncle Shakuni inspires to call on the Pandavas to Hastinapur and win their kingdoms in a game of gambling. "The plan's architect Shakuni was blessed with dice that would never disobey his will. The idea was that Shakuni would play against Yudhishthira and win at the gambling table what was impossible to win on the battlefield." ${ }^{10}$ As the game proceeded, Yudhishthira lost all his wealth and kingdoms one by one. Having lost all his material wealth, he was to put his brothers at stake one by one and lost them too. Ultimately, in the wake of momentary blindness and exorcism, he loses his wife too. The whole assembly starts hissing loudly when Yudhishthira stakes Draupadi "since the ownership of the wife by the husband was recognized but not respected in society." 11 So when 


\section{The Creative Launcher | Vol. 6 \& Issue 3 (August, 2021)|128}

Draupadi hears this news, she feels shuddered and questions the legality of the right of Yudhishthira to place her at stake. She out rightly denies the age- old female image of meekly obeying her husband Yudhishthira by sending back a query which no one could answer. She questioned her husband Yudhishthira if he had pledged her before or after he had lost himself in the gamble. She argued that if he had pledged himself first, he had no right over her as he was already a slave. She later challenged the game as illegal, as she argued that Duryodhana, a Kaurav, had not placed his brothers and wife as a matching stake.

Her protest, outspokenness not only underscores her reputation as a woman who unapologetically owns her freedom but also her individuality, audacity, the word 'woman power' does not just remain a phrase when one looks at the situation in the light of the socio- cultural milieu of the time:

At the time of Mahabharata, the society by and large was undergoing a transitory process. Matriarchal system was giving a way to Patriarchal society. At that time, ladies especially from royal families were not allowed to express their views in public. ${ }^{12}$ (Manimalini: (3-34)

Since her question was logical and context bound, everybody was dumb founded, tongue tied. It was also a challenge to Male-ego which provokes Karna, Duryodhana to exploit her. Karna calls her a public woman whose being clothed or naked is immaterial:

....The woman whom you are vehemently defending a faithful wife is not as faithful as you think... she is unchaste... she is a harlot... She revels in the physical enjoyment of five husbands... why five... She is the kind of woman who lusts for hundred and five husbands. ${ }^{13}$ (Shivaji Sawant Op.Lit.P-363)

The sensibility of her argument against accepting the slavery was so thought- provoking that one of Kaurava brothers Vikarna rushes to defend her, "The husband who has lost himself has no right to stake his wife...To molest a faithful wife is the death of Male chivalry" ${ }^{14}$ (Ibid).

Despite all this rebellion, the women critics like Iravati Karve have made Draupadi a centre of attack for the abrogation of norms unfortunately, "Draupadi's question did not involve any scholarly debate. The event was horrible... (her approach) was quite against the rules and regulations of the society..."15

One finds these views to be rather constructive and derogatory, to have sprung from a conformist state or internalized psyche, "compels women to stress from the point of view of men."16

But when looking at the situation with a dispassionate eye, it becomes crystal- clear what a sensitive issue it touches and makes one aware of the gravity of situation apart from making men aware of not to take women for granted or women are not to be silenced or for that matter dainty dolls, so will accept or blindly obey men.

\section{Limitations}

The research paper has confined itself only to the character of Draupadi and four novels, even when there are a lot number of writers to have touched different characters of Mahabharata with varying perspectives.

\section{Conclusion}

In the light of the above discussion, it is totally getting established that marginalisation or subordination of women in respect to men is not specific to a particular era. On the contrary, it was since time immemorial when men soon got to know the very spirit of femininity and "her womb got colonized." ${ }^{17}$ However, in no era, women had remained physically or artistically silent by accepting sorrows or subservience to be the ultimate fact of life (though their voices were either subsided or overlooked) as is the case with Draupadi, an exalted picture of womanhood, "the epitome of 
femininity and feminism." ${ }^{\prime 18}$ The way she faces the battle of obstacles in polyandrous and polygamous relationship really bears applause as Amreeta Syam points out her plight in her poem 'Kurukshetra':

Draupadi had five husbands but she had none,

She had five sons- and was never a mother.

The Pandavas have given Draupadi

No joy, no sense of Victory

No honour as wife

No respect as mother

Only the status of a Queen

Rather than operate within the system and yield to societal dictates blindly, she interrogates the validity of established norms by becoming a source of inspiration for many fair Ophelias and Tender Tess, underlining her as a complete woman of substance. Pradip Bhattacharya rightly says, "If the Mahabharata is an intricately woven saga of hatred and love, bloodshed and noble thoughts, courage and cowardice, beauty and gentleness, victory and defeat, then Draupadi is its shining jewel, casting the shadow of her towering personality over the epic poem and the all- destroying war it describes." 19 Making her stand not only the forerunner of Indian feminism but also the Oriental avant courier of Shaw's 'emerging new woman'.

\section{References}

1) Tapaswi, Suhasini. "Woman's Awakening Consciousness: A Study of Women Characters in Indian English Fiction." Indian English Panorama, edited by Rangarao Bhongle, September 1997, Santacruz ( E)

2) Beauvoir, Simone de. The Second Sex, tr. H. M. Parshley, 1953.

3) Abrahams, M.H : A Glossary of Literary Terms. (6 ${ }^{\text {th }}$ Edition). A Prism Indian Edition, 1993

4) www.wikipedia.com

5) Shri Manmahabharata (32 Vols): (ed) Rangaswami H.S et at. Bharata Darshana Prakashana

6) Bhagawat, Durga: Vyasaparva available on www.goodreads.com

7) Tiwari, Jyoti in her essay on Draupadi: The First Feminist available on www.merinews.com

8) Ibid

9) Ibid

10) www. wikipedia.com

11) Ibid

12) Manimalini. V.K: Draupadi: A Perspective in Indian English Panorama, September 1997,edited by Rangarao Bhongle, Santacruz ( E)

13) Sawant, Shiwaji: Mrutyunjaya: The Death Conqueror, English tr. By P. Lal and Nandini Nopany, Calcutta Writers Workshop, 1989

14) Ibid

15) Manimalini, V. K quotes in her essay Draupadi: A Perspective in 'Indian English Panorama', September 1997, edited by Rangarao Bhongle, Santacruz (E)

16) www-wikipedia.com

17) Alicewalkersgarden.com

18) Bhatacharya, Pradip in his essay on Draupadi: The Woman, Epitome of Feminity and Feminism available on www.dollsofindia.com

19) Ibid 